\title{
Fiction and Freedom: Janet Frame's Commitment
}

\section{Manon-Lili Morand}

\section{(2) OpenEdition}

1 Journals

Electronic version

URL: https://journals.openedition.org/ces/4949

DOI: 10.4000/ces.4949

ISSN: 2534-6695

\section{Publisher}

SEPC (Société d'études des pays du Commonwealth)

\section{Printed version}

Date of publication: 1 September 2015

Number of pages: 21-31

ISSN: 2270-0633

\section{Electronic reference}

Manon-Lili Morand, "Fiction and Freedom: Janet Frame's Commitment", Commonwealth Essays and Studies [Online], 38.1 | 2015, Online since 10 April 2021, connection on 10 July 2021. URL: http:// journals.openedition.org/ces/4949; DOl: https://doi.org/10.4000/ces.4949

\section{(c) (i) () $\Theta$}

Commonwealth Essays and Studies is licensed under a Licence Creative Commons Attribution - Pas d'Utilisation Commerciale - Pas de Modification 4.0 International. 


\section{Fiction and Freedom: Janet Frame's Commitment}

Janet Frame's oeuvre was much acclaimed by twentieth-century New Zealand which viewed in it an emblem of its own literary and cultural identity. Frame's singular and sometimes abstruse writing was initially quite rightly analysed through the prism of a post-colonial frame of reference. Yet, it shall be argued that Frame was never truly committed to a national cause. Her fiction is truly a commitment to freedom and writing achieved through a journey in imagination and fantasy, a faraway land that I will envisage as the workshop of artistic creation. Frame's literature of migration relies on such a movement of the mind, a movement inwards that paradoxically leads to a boundless universe of freedom.

Despite the fact that Janet Frame won international acclaim, and despite an abundance of very valuable reviews, articles and essays on her art, it is surprising to find that few sustained studies of her commitment as a writer have been published. Janet Frame was and still is a very puzzling author. Patrick Evans noted that her success happened "without the impetus of a unified critical understanding" ("Alienation" 294). He arguably pointed to the "difficulty of sensing immediately where the centre of her work lies" even though she is one of New Zealand's most acclaimed authors.

It would be tempting to define her as one of these post-colonial writers who committed their art to the promotion of their nation's cultural identity, but only on rare occasions does she fit that category. Commitment is indeed the aesthetic brand of many post-colonial authors, among whom writers such as Keri Hulme or Patricia Grace who were eager to promote and assert the cultural, historical, linguistic or even geographical particulars of their country, in opposition to what Bill Ashcroft, Gareth Griffiths and Helen Tiffin called a "privileging norm" in The Empire Writes Back (15).

Writing literally saved Frame's life and earned her not only freedom and a prestigious award, ${ }^{1}$ but also praise of a young nation eager to forge a cultural identity of its own. New Zealand, with its singular landscapes, pre-colonial myths and vernacular, is indeed an essential component of her work, a watermark neither to be ignored nor truly ostensible. Frame's literary inspiration is indeed ambiguous and multiple, as I will endeavour to demonstrate. It first originated in European literature, a fertile background she eventually outgrew but never disowned. Quite the contrary: she was purportedly attracted to British literature, whose traditions and codes she wanted to expand while indirectly paying tribute to its greatest authors through a rich intertextuality. Henceforth, Frame's work cannot be circumscribed within the boundaries of political or cultural commitment, whether it be about fulfilling the quest for identity of an infant nation or adding to the literary prestige of a millenary British culture. Frame's commitment is to be found elsewhere, anchored in the quest for her own identity as an author and poet whose singular voice and writing mingle different cultures and genres.

But if a social-realistic interpretation of literature does not apply easily to Frame's work, she is however famous for satirizing social conformity and the narrow-min-

1. She won the Herbert Church Award in 1951 for The Lagoon and Other Stories while awaiting a leucotomy, which was then canceled. 
dedness of her New Zealand fellow countrymen while still advocating the beauty of the country's wilderness. To assert that she conducted an unabashed, committed condemnation of her own country - or praise whereof - throughout her fiction would be a sterile reading grid. Janet Frame's commitment instead needs to be defined away from political or economic aspirations: only sporadically does she manifest a concern - if any at all - about colonization, social classes, even feminism or the politics of Englishspeaking nations in general. The notion of political commitment suggests a delineation of a homogenous social group, with its specific issues and causes that an author would defend, whether fervently or quite subtly, by way of a commitment through his/her art. Instead, Frame's largely autobiographical world abounds with singular dislocated individuals who never partake of a definite social entity but are rather identified by their unique, uncanny psyche. Most of her fiction exposes the destructive effects of society's conformism upon those individuals, something she experienced herself when she was committed to a psychiatric hospital for eight years, convinced of her own insanity, as she had wrongly been diagnosed with schizophrenia.

This aspect of her work has been widely analyzed by significant literary scholars in the light of Lawrence Jones's critical theory which pointed out "Frame's dualism between the sensitive individual and the uncaring world" ("No Cowslip's Bell in Waimaru" 295), opening the discussion about the antagonistic notions of imagination and reality that many scholars later resumed. Marc Delrez, Gina Mercer, Jeanne Delbaere and Claire Bazin, for instance, addressed those fundamental social issues which concern the ostracized. Jones argues that Frame's world of imagination, as a reclusive shelter for the individual, might have a metaphysical dimension but he does not reckon that there is a transcendental aspect to the human experiences she relates, arguing that they fail to reach universality as characters are presented as "types of the inevitable human tragedy" (68). He considers $\mathrm{Owls} \mathrm{Do} \mathrm{Cry}^{2}$ as failing to turn the specific and personal into the universal, a theory W. D. Ashcroft and Judith Dell Panny later added to by both their works on Frame's allegorical writing. I shall argue that the recent publication of Towards Another Summer finally sheds a new light on this question by allowing a more transcendental reading of her fiction as a whole. The posthumous novel, which was deemed too personal to be published in Frame's lifetime, functions as a keystone to her whole corpus and its wide network of echoes.

I intend to show that Frame's commitment, though it may have merged into the celebration of her newly emancipated country's identity, is truly a commitment to writing as an act of universal significance that transcends all collective identities. I will envisage her writing as a movement inwards, which paradoxically evolves towards freedom, a literal aspect of her life - as she was indeed freed from a psychiatric hospital thanks to her talent as a writer - which metaphorically transfers to her fiction to ultimately reveal the universal expressions of her poetics of migration.

To really fathom Frame's commitment requires going beyond the myth of her own existence as an outcast, and beyond the renowned three-volume autobiography that nonetheless shaped the early literary criticism of her fiction, as Frame did create heroines that resemble her and share similarities with her own life. I have thus chosen to focus essentially on her corpus of long and short fiction, which I will consider as a continuum

2. Owls Do Cry was Frame's first novel, published in 1952. 
of work rather than separate, disconnected pieces, with specific references to her posthumous novel. Frame's numerous fictionalized doubles, providing substantial material on her real, somehow personal commitment - or absence thereof - will be envisaged as emblematic figures of their author's ontology.

\section{The Bounds of Commitment}

Janet Frame's writing encompasses much of the post-colonial issues that were to define New Zealand's twentieth-century literature (Ashcroft et al.). Her work stems from her childhood spent in New Zealand as the child of an impecunious family where it was deemed essential to conform to British middle-class values. Her fictional yet largely autobiographical world shows how her native land aspired to be the antipodean duplicate of British society with its moral values, language and way of life. Very often, the characters of her fiction and narrators, whether children, outcasts or fictionalized doubles, suffer from this long-distance cultural commitment to a hegemonic Britain that does not account for their antipodean difference: "“you are a long way from home' Trinity said. 'New Zealand is at the end of nowhere," is one comment made to Mavis Halleton, New Zealand expatriate writer and heroine of Living in the Maniototo (8). Such a statement pertains to a whole demonstration aiming at pointing that New Zealand is far from the "centre" of the world, namely Britain. Frame often stresses New Zealanders' institutionalized desire to duplicate Britain, as manifest in the short story "Miss Gibson and The Lumber-Room" (in Lagoon), where a teacher reads the story of a young woman's unreeling thoughts upon entering her "lumber-room" - a cliché of British well-off mansions - and commands her pupils to write on the same subject, an opportunity that the creative child-narrator seizes to elaborate a fertile, imaginative account of her would-be British life, invoking colonial clichés in a fancy story that could be read as a post-colonial statement. By being ironic about colonial pride and putting forward an excessive rhetoric in the description of the furniture and way of life, the child mocks what was generally acknowledged as a model by New Zealand society. The lumberroom could also symbolically stand for a storage of a nation's memories and souvenirs of past history, something New Zealand as a newly emancipated country is relatively bereft of once rid of its colonial history. But Janet Frame's writing actually proposes to go beyond these clichés and discrepancies between a Eurocentric model and the young nation she writes about.

As in most of Frame's other pieces of fiction, the short story shows a narrator with an archaeological gaze, which sees and seeks beyond the given realities of the world surrounding her, digging out through mantles of history in which individuals innocuously exist. Her novel The Rainbirds probably offers the best example of this phenomenon, as it presents New Zealand as a country where war memorials are used as "public lavatories or tea kiosks," (233) whereby Frame highlights, in the comic and satirical register, a gradual erosion of the collective memory regarding the impact of invasion (Cronin and Drichel 136). Although war memorials no longer seem to hold the meaning they were initially given, their mere evocation in the narrative quickly reminds the reader of the country's violent past. The novel is indeed structured around the war metaphor and its latent violence, which debunks the myth of a war-free New Zealand that the main protagonist, Godfrey Rainbird, has sought as refuge after leaving London during the Second World War: 
How fearful, irrevocable pronouncements were! The Air Ministry had made a pronouncement. The War Office. Pronouncements, Bulletins, the details of the raids; the casualties; all the official words webbing themselves about the idea of pronounced death. (55, emphasis added)

The capital letters graphically expose the social and institutional disguises put on by words (Bazin \& Braun 104), with a deflating irony that recalls what those terms truly foreground: death. In that respect, if any post-colonial reading of Frame can be made here, it is by dint of this discrepancy between the perception of oppressive history the narrative tale of European imperial expansion that Frame's child-narrators often denounce - and the prosaic yet universal reality any political or social discourse foreshadows. However, Frame and the protagonists of her fiction never truly commit to the political causes they mock, merely exposing their ironic turns.

This need for a linguistic and cultural connection with the Northern hemisphere is also subverted in Living in the Maniototo by people's enthusiasm when the city of Blenheim - here a fictional suburb of Auckland - is twinned with that of Berkeley, in California, a social celebration to which the heroine does not commit, displaying a patent absence of personal involvement that spans all levels of her existence: "Our marriage was not excessively happy. We plodded along because we'd been taught to, by the examples of our parents [...], we'd been taught to think of our country, its peoples and history" (17). The choice of city name is also ironic in itself: Blenheim is a famous, monumental aristocratic castle in Oxfordshire. The heroine further stresses and exposes her compatriots' failure to equate Britain's art in general with the eye of a non-committed observer and a mocking tone: "I discovered that the house itself was full of likenesses, of replicas, prints of paintings, prints of prints, genuine originals and genuine imitation originals, imitation sculptures and twin original sculptures" (9). This is an example of what Edward Said termed a "conscious affiliation" (qtd. in Ashcroft et al. 16), that is to say "a mimicry ${ }^{3}$ of the centre proceeding from a desire not only to be accepted but also to be adopted and absorbed. It caused those from the periphery to immerse themselves in the imported culture, denying their origins in an attempt to become more "English than the English" (17). The same can be said about Owls Do Cry, which granted Frame an international reputation. Some New Zealand contemporary critics regarded this account of the life of the Wither family and their town as a social satire of the habits and opinions of the townsfolk. Frame comically denounces the materialism of an impoverished, post-war New Zealand fighting its way back towards affluence and self-assessment, but the novel does so through the narrative prism of a child, whose genuine wonder at the oddities of the world cannot be presumed to hinge on social realism, again hinting at Frame's lack of this form of commitment. She rather appears a detached, bemused commentator on her country's servitude to Britain, an idea that creates a backdrop to her fictional universe rather than being a cause to defend or to reject.

Grace Cleave, Frame's fictional double in Towards Another Summer, spends a weekend at her English friend's, living immersed in his family in the manner of an anthropologist who hopes to discover how such a human group functions and how to fit in. There she is a disappointing, shy guest, unable to produce anything but a few platitudes, as if this

3. On mimicry, see of course Bhabha. 
scarcity of words echoed the supposed cultural deficiency of her native country, something she enhances by a fragmented and enigmatic syntax: "In my own country. [...] Then it was At Home, Back Home, Where I come from... It's funny over here, you... whereas we always..." (4, emphasis added) Frame's prevailing themes and stylistic signature are noteworthy here. Again, the capital letters endow the terms they designate with an ironic, ambiguous distance while the syntactic structure is disrupted by aposiopesis - the figure of the unsaid - leaving linguistic gaps to be filled by an interpretive act of reading and where imagination can be deployed. Those syntactic silences also give the overall idea that communication with the motherland has been disconnected, missing some parts of the sentence to make it a clear statement. This linguistic disjunction might also account for Grace's impossibility to communicate her thoughts with words whose original meaning has been perverted by society's hackneyed use of them. What "Home" and "World" mean are precisely fundamental questions that all of Frame's narrated selves and protagonists find no answer to: "Where is the world?" "Where am I $[\ldots]$ ? [...] there is no place for me" (Owls 99). This recurring stylistic signature also prevails in Frame's other novels: the meaning of words is corroded and language becomes a social tool aimed at isolating individuals from the community they were born in $(\mathrm{Ba}-$ zin, Janet Frame 7). Words are bereft of true meaning, they are only platitudes and clichés devoid of interest and accounting for a lack of personal commitment, as Grace Cleave rightly pinpoints: "Was there, after all, some communication on this weekend of platitudinous I like your cooking, You're good with children, yes I like Winchley?” (Summer 112) Grace's silence throughout the weekend also metaphorically seals the antagonism between the two hemispheres, as it seems to suggest the symbolic death of a common language. The cord is severed and the exile is final. However, the parted worlds will eventually be reconciled by a trope that weaves an invisible thread between them: "I'm a migratory bird," (22) an allegorical chorus by which the author/narrator proclaims her multifaceted identity and the universality of poetic language.

Grace, Mavis and others, like Frame herself, are all figures of expatriate writers. New Zealand did shape Frame's way of thinking, as the country's societal and linguistic singularities are often brought forth in her novels. New Zealand, however, is not to be considered as a model: if it is constantly evoked and brought into the narrative whenever antipodean oddity is at stake, it is altogether presented as a burden Frame intends to be relieved of. Writing "I was a certified lunatic in New Zealand. Go back? I was advised to sell hats for my salvation" (Summer 14) is a bitter comment, which nonetheless does not indicate that she erects Britain as superior either. She often points out that Britain, and Europe in general, are as toxic as New Zealand: "She [began] to scratch; her sores were mapped red like the countries of the British Empire in the Atlas" (Summer 131). This incongruous analogy between skin-deep reaction and the reminiscence of British colonization could suggest Frame's refutation of British hegemony. However, her position remains ambiguous and undecided. Indeed, although her fiction depicts characters obsessed with the idea of going "back home," she herself fled New Zealand with the burdensome, ostracizing label of schizophrenia, and returned there only to live as a recluse.

Most of Frame's novels stage heroines who are committed to psychiatric institutions and are reasonably assumed to be Frame's fictionalized doubles. One of them, Istina Mavet, the heroine of Faces in the Water, writes: "I was put in hospital because a great 
gap opened in the ice floe between myself and the other people whom I watched [...] I was not yet civilized; I traded my safety for the glass beads of fantasy" (Faces 10-11). In her autobiography, Frame herself recommended this novel as a documented account of her own experience, thus revealing her personal committed view that civilization is a social, paralyzing construct which she is not part of. In the whole novel, Istina commutes back and forth between being "well enough to be released" (33) and being "beyond hope," (36) even threatened with leucotomy as Frame was, a dramatic impending fate that reveals society's coercion over those who do not fit in and fail to match conformist expectations. As has been well demonstrated by many scholars, this is a cause Frame was really committed to: speaking for the outcasts who are always at the periphery of the world, giving them a voice through literature and poetry.

In this respect, distance, whether through a self-imposed triple exile - linguistic, cultural and geographic - in the case of Grace or passively endured in the case of Istina, in fact appears as the very opposite of commitment, a way for the author never to engage in human and social interaction, except by looking at it from afar, having been relegated to the margins of society. However, Faces in the Water, The Edge of the Alphabet and Scented Gardens for the Blind are all concerned with characters trying to find their way back to New Zealand - or one should say to the "Is-Land," to take up the famous pun made in the autobiography. "All writers are exiles wherever they live," Frame proclaimed at the end of her third and final volume of autobiography, The Envoy from Mirror City, "and their work is a lifelong journey towards the lost land" (178). Therefore, Frame's absence of commitment is an experience of unsettlement, of being out of place and being a lonely wanderer of the world, unable to settle. This incapacity to anchor is a question that has only indirectly been addressed (Blowers) and needs further probing into. All of her fiction - and particularly Towards Another Summer and its free-bird metaphor - is steeped in such melancholic meandering. Its aesthetic tonality is underpinned by the tropes of journey and quest, revealing another form of commitment which is a predominant component of her fiction, a commitment to writing as an artistic act transcending all collective entities and reconciling one with one's own sense of being part of the world though never touching the ground.

\section{A Commitment to Writing: The Free-Bird Metaphor}

While Frame is not literally a migrant writer directly addressing the question of exile (Childs), it can be argued that she thoroughly explores the theme of migration through spiritual journeys and quests, making it the fabric of her poetics. Her characters, as well as her use and examination of language and narratives, are inscribed in a journey of solitude that aims at re-defining their essence on a spiritual, and even metaphysical, level. Most of Frame's protagonists are indeed outcasts in search of their own "place to be-long," (Rainbirds 83) a double literal quest that imbues the physical with the metaphysical so as to finally transcend the boundaries between the two. Most of those protagonists are engaged in a quest for their own anchorage, which we understand as a connection to the world, of which Towards Another Summer provides a case in point: Grace Cleave is both a literal and metaphorical explorer. She is a New Zealand writer expatriated in London where her sense of place and being is constantly displaced and estranged: "Oh God why have I been deceived? Which world do I inhabit?" (19). As in many of Frame's novels, the textual reality of Towards Another Summer is confusing as 
several narrative strata are superimposed, forcing the reader to shuttle back and forth, sometimes disturbingly within the same paragraph, between analeptic reminiscences of the girl's childhood, proleptic fantasy, daydreaming, poetic breakthroughs - in prose free verse, or even rhyming singing - in a complex embedded and polyphonic narration that is difficult to sort out, evoking Virginia Woolf's stream of consciousness technique. The migrant, like a wanderer of the mind, draws her displacement on the narrative map. Hence Grace's concern for something she calls "my place," an ever-shifting mindscape and the boundless locus of her poetic fabric: "my place followed me like a shadow and it is always near me, even here in Winchley, and I do not even need to close my eyes or call for silence before I am there," (Summer 56) thus revealing how imagination and poetry can transcend the initial geographical sense of place and anchorage to allow another kind of connection to the universe.

Grace's "place," like Frame's, goes back to the initial place where her mental existence began: "we return again and again to the birth of the thread, the Where" (Ow/s 43). It might be argued that here birth is mental rather than physical, and points to the birth of the artist through his/her writing. The being is anchored in imagination and not in the actual, physical world. Frame's poetics of migration is encapsulated in this notion of transcending physical places and existence through literature and poetry, in a movement from the physical to the metaphorical and even the metaphysical. Like the migratory bird she repeatedly declares having been changed into, Grace proceeds to outgrow her human, earthly, cramped envelope by flying above the terrestrial surface, towards freedom and a place to settle in, anchor and be-long. This metaphorical resurrection as a bird can be read as a form of transmigration of the soul, a continuation of her spiritual life after death, a trope which can also be found in The Rainbirds, which makes Frame's metaphysical concerns clearer. The protagonist indeed experiences a literal yet poetic death and a resurrection. But Towards Another Summer, with the trope of the migratory bird, is probably the novel that most explicitly enacts this interplay between the physical and the metaphysical. Migration occurs between the realization of one's isolation and a questioning about the essence of being.

Frame's fiction therefore articulates cycles of being and not being, in relation to the themes of isolation and war that she already attempted to universalize in the Edge of the Alphabet, in which dreadful war bombing is compared with prosaic domestic images, such as the "terrible hoover at the top of the stairs and the way [our] identity has been sucked in with the others so that in the dust and suffocation of the bag which contains us all [we] cannot tell [our] own particles" (107). This analogy could evoke the universality of the abomination of the holocaust: man-cleaning and even race-cleaning like impersonal dust irremediably sucked up into the vortex of the indifferent vacuum cleaner (Delrez 147). Owls Do Cry also seems to be an attempt at transcending its own war metaphor to make it universal, although it has been pointed out that "this is made with some difficulty" (Evans 203). Toby's story which he entitles "The Lost Tribe" could not only be read as emblematic of New Zealand's indigenous populations, but also universally evokes various groups of eclipsed humanity in the course of history and even prehistory and protohistory. Frame's concern with migration, which can be interpreted as a trajectory from a literal towards a metaphoric and finally a universalist motif of migration, could express ontological concerns, to which she really commits as a writer. But this humanist reading of Frame, which presupposes the existence of 
a transcendental concern underlying her fictional universe, could obliterate a more literary and poetic analysis of her protagonists' peculiar mindscapes. That being said, her concern for ontology is undeniable in her fiction, and some scholars - most notably Jeanne Delbaere - have argued that Frame might have been openly influenced by Martin Heidegger's being-in-the-world philosophical concept, although this remains an open debate. At the very least, in all of her fiction, places undoubtedly appear more metaphysical than physical or ideological. But above all, they are very poetic and stem from the realm of imagination, a world to which Frame was truly committed and which allows her to anchor in the world.

Frame's true commitment was indeed to writing, to words and their multiple meanings, to poetry and to artistic creation. Her narratives reveal a commitment to language by the way she turns it into a playful exploration field. Her literature of migration also hinges on language, as words undergo an evolution through most of her narratives. Like the child entering the adult world, her narrators experience the drastic shifts that affect the meaning of words. Frame points to this dichotomy between signifier and signified in her autobiography: "learning words, I believed from the beginning that words meant what they said" (Autobiography, Vol 1, 89), revealing the innocence of children, only to become corrupt upon entering adulthood. This is a recurring motif in her fiction that also provides material for her poetics: "tools for communication have crumbled to reveal the broken teeth of language" (Alphabet 93). The inherent nonsense of language foreshadows its inability to state or to name what is or is not, which is magnificently emblematized by the pouring midnight rain that finally destroys human language at the end of The Carpathians, Frame's last novel. This apocalyptic regenerative outcome metaphorically echoes Scented Gardens for the Blind as Vera's ultimate inarticulate groan is paradoxically presented as "the language of humanity," as a return to a precivilized, uncorrupted world (251). The end of The Carpathians sheds light one last time on Frame's lifelong concern with language and its legacy through subjective narratives told by outcasts, as Mattina, the only survivor of the cataclysm, is entrusted with the mission of remembering and transmitting her story to the world, a mission only literature can fulfill.

Most of Frame's work deals with the subjectivity of words and their interpretation, their evolution and ever-shifting meaning, usually in the satirical mode, to denounce their duplicity. But this linguistic migration also gives her the opportunity for a unique artistic creation. She did consider her fiction to be more a form of "exploration rather than novels" (Janet Frame in her Own Words 66). Words are an inexhaustible source of inspiration for her, and they reveal the poet's ethics, as Frame was a fervent defender of "creatures who are beyond the range of words" (Alphabet 16). Like her fictionalized double, Istina, who regrets the fact that fairy-tales have been "thrown away because [they] did not any more speak the right language, and the people could not read [them] because they could not find the way to [their] world" (Faces 14), Frame aims at exploring and going beyond the edge of the English language by constantly playing on the evershifting meaning of words and the abounding possibilities for new wordplays: "Frizzle - Freezing rain plus drizzle! New word for weather! It's not often, Grace thought, that the language is made a headline" (Summer 31). Words and the discrepancy between their written manifestations and their spoken utterance are always a source of literary amusement for Frame. Her protagonists, especially children, are able to construct and knit 
incredible tales from the mere evocation of a single word, which, thanks to its network of mental images and subconscious cross-references, evokes a whole range of other images and makes for the construction of a fancy universe. For instance, the pun on dual/jewel in The Edge of the Alphabet hints at the inherent artistic potential of words and their homophonic correspondence.

In Frame's fiction, language is a playground and writing, in the broadest sense, is experimental. Much of Frame's work shatters the conventional elements that constitute a narrative: characters, plot-threading, and even time and space. Frame's fiction switches narrative modes and viewpoints, giving voice to unstable and unreliable narrators - even impostors, for instance in The Carpathians - who shift from the first-person to the third-person pronoun, like Grace Cleave, thus undermining the univocity of her narratives. Frame's stories are rarely chronological; they are rather a blended flow of moments, conversations and insights, sometimes inspired by a seemingly random choice of words and by objects excavated from the past, quarried from the imaginative mind. Hence Frame's persistent reputation for being difficult to read. But her commitment to writing is also graphically materialized by her experiments with metafiction. Indeed, among numerous other styling techniques, Frame immerses herself in her own fiction - the ultimate act of commitment - by way of narrated selves that she embodies. She seems to be voluntarily blurring the demarcating lines between herself, her narrators and heroines. She often uses the self-fictional "I" as an unstable deictic that fails to anchor in the text. Metafictional narratives tend to generate confusion between genres, something Frame's fiction tends to further enhance by an idiosyncratic use of punctuation - or lack thereof. If Frame's numerous narrated selves are firmly grounded in her autobiographical reality - we may think of Grace Cleave but also Istina Mavet or Daphne Wither who recount their experience of mental asylums - they are nonetheless heroines of fiction who relate events through all the subjectivity of their own narrative prism, thus not always matching Frame's own history. Frame did explicitly point out in her autobiography that she never really wrote about herself:

When [Owls Do Cry] was published, I was alarmed to find that it was believed to be autobiographical, with the characters actual members of my family, and myself the character Daphne upon whom a brain operation was performed... Daphne resembled me in many ways except in her frailty and absorption in fantasy to the exclusion of "reality." I have always been strong and practical, even commonplace in my everyday life. (Autobiography, $\mathrm{Vol} 2,98$ )

That being said, her fictional variations on the autobiographical genre even precede the postmodernist label that was to occupy the stage of literary criticism for half a century. ${ }^{4}$ Metafiction could be interpreted as proof of a writer's personal commitment to his/her own writing. In that respect, Frame's work may have been visionary, as it proposed to transcend the dichotomous rupture between fiction and reality, hinting at the postmodernist notion of subjective narration. It is precisely the subjectivity of Frame's tales with its bizarre use of language that paradoxically carries the best possibility for any prospect of poetic transmission. In fact, Frame's entire oeuvre concerns the subjective telling of tales by eccentrics that are on the margin, precisely on the edge of the alphabet, like Mattina at the end of The Carpathians or Thora Pattern in The Edge

4. A thorough analysis of Frame's postmodernism will be found in Suzette Henke. 
of the Alphabet. This trope of the individual tale is the manifesto of Frame's ethics of transcendent writing, which always goes beyond what is given to see on the page and in the diegesis, hence appealing to our wide imagination and capacity to decenter our viewpoint by adopting a more creative perspective on our preconception of what reading a novel means. Any attempt at constructing a definite frame of reference or a reading grid collapses at once in Frame's fiction: the separation between the real and the imaginary, but, to a larger extent any kind of dual opposition - here and there, near and far, then and now, earth and sky, even I and you - are properly debunked. Those oppositions are shown as cultural constructs to be overridden, a consequence of defining fixed entities by antagonism. ${ }^{5}$ This is something Frame expounds in her fiction. It is also in that sense that her writing can be called literature of migration, as her texts demonstrate that the experience of "being" requires going beyond one's own initial definition of identity by embarking on a solitary journey in the land of imagination and poetry: "I think a writer needs to lead a solitary life. When I say that, you have to be in isolation to do your work. After you've done your work, well that's another matter!" (Alley and Williams 103)

Frame's writing may not be conventional in many regards, but her corpus abounds with modernist, poetic masterpieces, bearing witness to her wide reading - William Faulkner, Virginia Woolf, James Joyce, Frank Sargeson, Katherine Mansfield, Charles Brasch, even the brothers Grimm and many others. But her purpose was not to imitate or pay a tribute to other writers. On the contrary, she intended to claim her singularity by getting rid of social dictates in her writing, and to assert her own, unique and singular poetic voice, always refuting the notion of literary frame: "Unfortunately [she] was one of those people who can become a bore and irritation to others and an anguish to themselves because their lives are dominated by 'ought," writes Grace Cleave (Summer 87), a comment Frame could have written about herself. The playful, almost facetious irony contained in her own statement precisely invites the reader to regard her as a witty writer mastering the art of rhetoric as Frame is indeed no "bore."

Janet Frame's whole corpus needs to be envisaged as an act of universal experience. Her commitment to writing is that of liberty, as all her individual characters - and herself as an author - are identified by an inner freedom, whatever their situation in the physical world, even as lunatics locked up in mental hospitals. They live in the boundless universe of the imagination which Frame's textual space represents. In her fiction, each human sensory experience - walking, seeing, hearing, speaking, interacting - marks a departure from the physical world to that of the imagination and poetry, a never-ending journey that goes beyond any kind of initial political or cultural commitment. To this extent, she transcends the notion of commitment to the outer world by paradoxically remaining on the level of intimacy and inner, mental, even secret experience that she finally erects as a universal and transcendent parable with Towards Another Summer.

Manon-Lili Morand

Université de Toulouse III - Paul Sabatier 


\section{Works Cited}

Alley, Elizabeth, and Mark Williams. In the Same Room: Conversations with New Zealand Writers. Auckland: Auckland UP, 1992.

Ashcroft, Bill, Gareth Griffiths, and Helen Tiffin. The Empire Writes Back. 1989. London: Routledge, 2002.

Ashcroft, W. D. Beyond the Alphabet: Owls Do Cry. Sydney: Dangaroo, 1992.

BAzIN, Claire. Janet Frame. Tavistock: Northcote, 2011.

—, and Alice Braun. Janet Frame, The Lagoon and Other Stories: naissance d'une oeuvre. Paris: PUF, 2010.

Bнавна, Homi. The Location of Culture. London: Routledge, 1994.

Blowers, Tonya. Locating the Self: Re-reading Autobiography as Theory and Practice, with Particular Reference to the Writings of Janet Frame. Ph.D thesis, U of Warwick, 1998.

ChILDs, Peter. Post-Colonial Theory and English Literature: A Reader. Edinburgh: Edinburgh UP, 1999.

Cronin, Jan, and Simone Drichel, eds. Frameworks: Contemporary Criticism on Janet Frame. Amsterdam: Rodopi, 2009.

Delbaere, Jeanne. "Turnlung in the Noon Sun: An Analysis of Daughter Buffalo." The Ring of Fire: Essays on Janet Frame. Ed. Jeanne Delbaere. Sydney: Dangaroo, 1992. 161-76.

Dell Panny, Judith. I Have What I gave: The Fictions of Janet Frame. 1992. New York: George Braziller, 1993.

Delrez, Marc. Manifold Utopia: The Novels of Janet Frame. Amsterdam: Rodopi, 2002.

DerridA, Jacques. De la grammatologie. Paris: Minuit, 1967.

Evans, Patrick. "Alienation and the Imagery of Death.” Meanjin Quaterly 32.3 (1973): 294.

- Janet Frame. Boston: Twayne, 1977.

Frame, Janet. The Lagoon and Other Stories. 1951. London: Bloomsbury, 1997.

—. Owls Do Cry. 1961. London: The Women's P, 1996.

—. Faces in the Water. 1961. London: The Women's P, 2000.

- The Edge of the Alphabet. New York: George Braziller, 1962.

- Scented Gardens for the Blind. New York: George Braziller, 1964.

- Yellow Flowers in the Antipodean Room (The Rainbirds). New York: George Braziller, 1969.

-. Living in the Maniototo. 1979. Auckland: Random, 2006.

—. The Carpathians. 1988. Auckland: Random, 2005.

—. The Complete Autobiography. 1990. London: The Women's P, 1990.

-. Towards Another Summer. Auckland: Random, 2007.

- Janet Frame in her Own Words. Ed. Denis Harold, and Pamela Gordon. Auckland: NZ Penguin. 2011.

Henke, Suzette. “The Postmodern Frame: Metalepsis and Discursive Fragmentation in Janet Frame's The Carpathians." Australian and New Zealand Studies in Canada 5 (1991): 29-38.

Jones, Lawrence. "No Cowslip's Bell in Waimaru: The Personal Vision of Owls Do Cry." Landfall 24.3 (1970): 280-96.

—. Barbed Wire and Mirrors: Essays on New Zealand Prose. 1987. Dunedin: Otago UP, 1990. 